\title{
上肢末梢神経麻痺に対する治療の検討
}

\author{
九州大学医学部整形外科 \\ 光 安 元夫 - 内 村 正 英 \\ 河崎 可昭
}

\section{A Follow-up Study of Peripheral Nerve Palsies in the Upper Extremity}

\author{
by \\ M. Mitsuyasu, M. Uchimura, \& K. Kawasaki. \\ Derpartment of Orthopedic Surgery, School of Medicine, \\ Kyushu University.
}

\begin{abstract}
This study is based on the analysis of the results of 152 peripheral nerve palsies in the upper extremity treated by neurorrhaphy or neurolysis from 1960 to 1972 .

There were 81 neurolysises, 69 neurorrhaphies and 2 nerve grafts. The assessment of recovery was made on a neurological basis according to the British method.

The results of neurolysis and neurorrhaphy were analyzed with respect to the level of injury, delay of repair, age of patient. The results of 2 nerve grafts were also assessed.
\end{abstract}

末梢神経の手術, 特に神経縫合術では, 予後の推測 が困難であり，一般的にその予後は決して良好である とはいえない。近年 Sunderland 等は末梢神経の funicular topography の研究にもとづき, funicular suture を提唱, わが国でもその試みがなされつつあ り, 従来の外神経粗縫合に対し種々の疑問がなげかけ られている，当教室で過去 13 年間に行なってきた上 肢の末梢神経の手術につき, その治療成績の調査を行 ない，外神経鞘縫合法の問題点を考察するために以下 の検討を行なってみた。

調查対象, 当教室において, 昭和 35 年から昭和 47 年までの 13 年間に.上肢末肢神経の手術を行なったも ののうち, 125 症例, 152 神経について調查を行なっ た.てれらのうち今回直接検晾しえたものは 30 名, 39 神経であり, アンケートにより回答を得たものは 28 名, 33 神経であった.

まず手術法について述べると, 神経縫合術は全例, 外神経鞘縫合法である. 神経剝離術は生食を利用した 神経鞘内剝離術が行なわれている。 また, 神経移植を 行なったものは，2名にその回答を得たが，1例は前 腕の高度挫滅創を伴なう正中尺骨神経麻瘏で, 創の治 療を待って，尺骨神経を儀牲にしてれを正中神経へ移
行する pedicle nerve graft を施行した. (症例 20), また他の 1 例は $\mathrm{Co}^{60}$ 照射同種神経移植で, 術後の回 復は不良であった（症例 17）.

治療成績判定基準. 成績の判定には Highet の基準 を改良した Sakellarides の基準をもとにし，運動機 能では手指の変形, 筋菱縮, 自動運動域, 把持機能, 筋電図所見等を, また知覚機能では触覚検查, 痛覚検 查, 2 点識別検查, coin test, 発汗機能検査 (桜井, モンタナ法）等を参考にした. 判定基準の good, excellent, すなわち, 知覚においては $\mathrm{S}_{2}{ }^{+}$以上と判定 されたもの，また運動機能においては正中神経では $\mathrm{M}_{3}$ 以上, 尺骨神経では $\mathrm{M}_{2}{ }^{+}$以上のものを useful recovery と評価した。

\section{治獠成績}

1. 神経剝唯術. 表 1 亿示すでとく対象は 31 名中 34 神経である. 橈骨神経麻痺は 11 例で, 注射によるも のが 5 例含まれており，乙れらは比較的術後の回復は 良好であった。また 18 例の尺骨神経麻痷のうち 11 例 の遅発性尺骨神経麻瘦があり，いずれも神経移動術を 併用しているが, 術前経過が長いものも多く, 半数近く に成績不変例をみた。正中神経麻神は 5 例であった。

2. 神経縫合術, 対象は 26 名, 35 神経であり, 表 
表 1 神経剝離術の治療成績

\begin{tabular}{|c|c|c|c|c|c|}
\hline & $\begin{array}{c}\text { 症例 } \\
\text { 数 }\end{array}$ & 治療 & 軽快 & $\begin{array}{c}\text { 不変〜 } \\
\text { やゃ } \\
\text { 軽快 }\end{array}$ & $\begin{array}{l}\text { 評価 } \\
\text { 不能 }\end{array}$ \\
\hline $\begin{array}{l}\text { 暁骨神経 } \\
\text { 正 中神経 } \\
\text { 尺骨神 経 }\end{array}$ & $\begin{array}{r}12 \\
5 \\
18\end{array}$ & $\begin{array}{l}6 \\
3\end{array}$ & $\begin{array}{l}4 \\
2 \\
7\end{array}$ & $\begin{array}{l}2 \\
2 \\
6\end{array}$ & $\begin{array}{l}1 \\
2\end{array}$ \\
\hline 計 & 35 & 9 & 13 & 10 & 3 \\
\hline
\end{tabular}

2 亿示すごとくである. 術後経過年数は 最長 13 年 6 力月, 最短 6 力月で，平均経過年数は 7 年である。 ま ず運動機能についての useful recovery は橈骨神経 では 5 例中 4 例, 正中神経では 13 例中 7 例, 尺骨神 経では 15 例中 11 例となる.つぎに受傷から手術まで の期間と回復状態の関連性は運動機能の面からは 1 力 月以内では 12 例中 10 例, $1 \sim 6$ 力月では 14 例中 7 例, $6 \sim 12$ 力月では 7 例中 5 例に useful recovery がみられた．知覚については縫合時期との関連性はと くに認められなかった。 また受傷部位からみた運動 機能の改善度では, 中間位は症例数が少く除外する が，高位では 15 例中 10 例，低位では，14 例中 9 例 が useful recovery を示し, 損傷高位別による予後 の差は，はっきりしなかった，知覚の回復も約 $60 \%$ に満足すべき改善をみたが, 損傷高位による予後の差
は認められなかった. 知覚の定位錯誤は, 6 神経に 認められた。各症例の受傷時年令, 術後経過半数, 機 能状況は, 21 才 10 年半 $\mathrm{S}_{2} \mathrm{M}_{4}, 27$ 才 10 年半 $\mathrm{S}_{3} \mathrm{M}_{3}$, 25 才 10 年 $S_{3} M ?, 27$ 才 10 年 $S_{3} M_{3}$, 28才 4 年 $\mathrm{S}_{3} \mathrm{M}_{4}, 36$ 才 3 年 $\mathrm{S}_{2}+\mathrm{M}_{4}$ であった. 27 才で術後 10 年 の症例は，正中尺骨神経麻瘏で，正中神経に対し有茎 神経片移植を行った症例で, その錯誤の状況を図 1 に 示す.

\section{局所識別の錯誤}

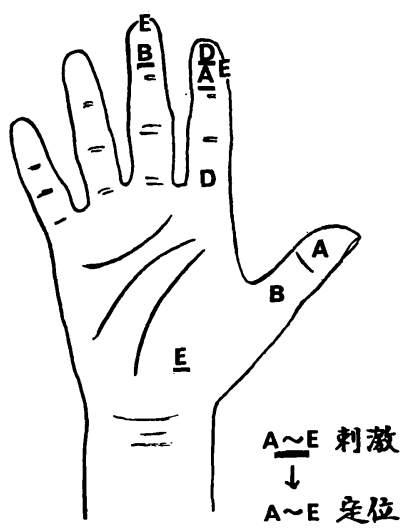

図1 有茎神経片移植後10年

表 2 神経䒃合術の治療成積

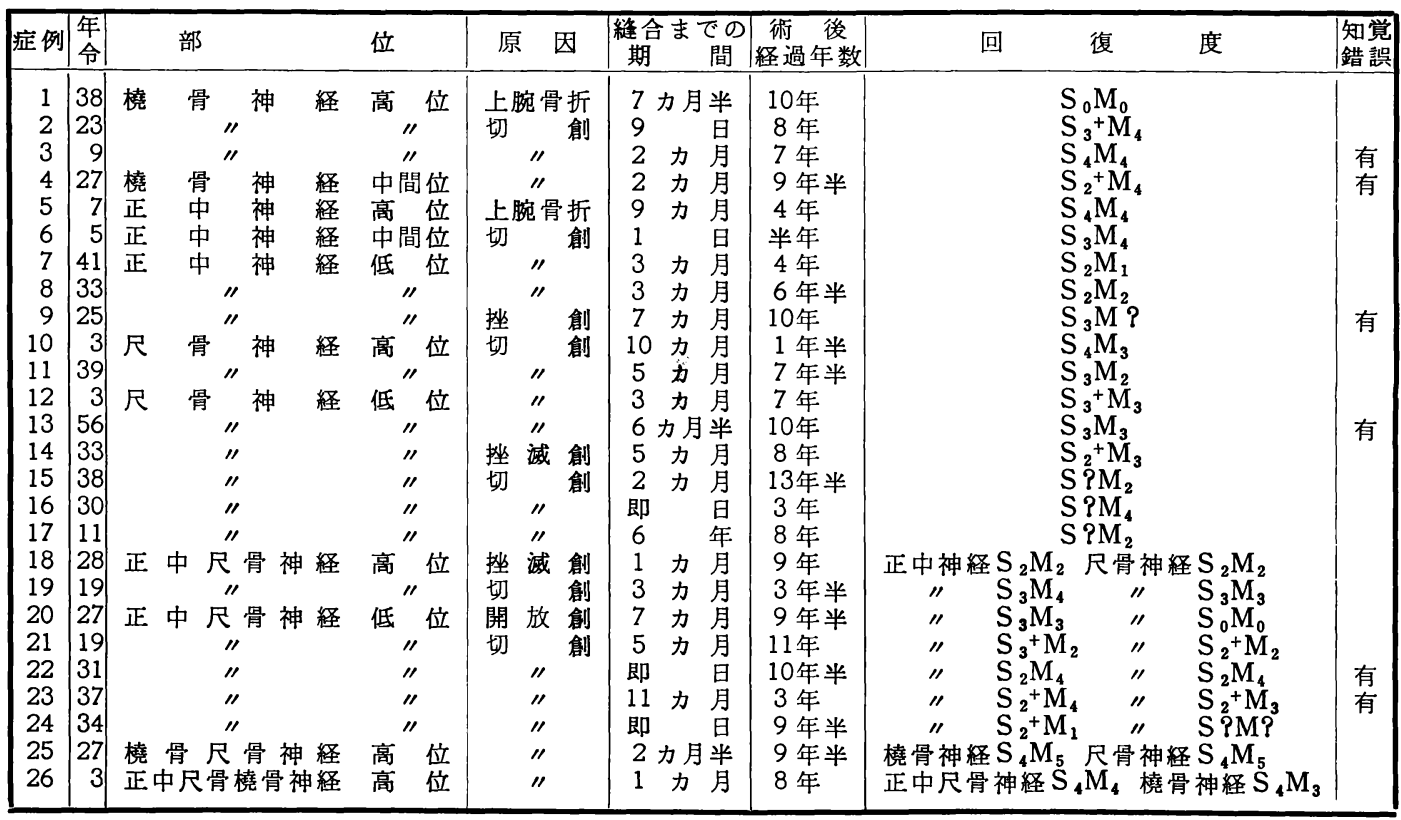




\section{考 察}

神経麻瘏の治療成績を左右する因子としては, 損傷 高位, 手術時期, 手術手技, 損傷神経の種類, 神経縫 合部の緊張の程度, 受傷原因, 年令等があげられる. 今回は, 受傷部位, 手術時期と予後との関連性を検討 した。一般には，高位損傷の方が成績が良く，受傷よ り手術までの期間は早期程予後は良好で, 18 力月をて えると運動機能の回復は起り難いといわれている. われわれの 1 年以内の症例では, 時期的な優劣は判定 できなかった。また, 高位麻瘏も, 低位麻瘏と同様の 回復を見た事は興味深い点である、神経別にるる機 能改善度も大差無いが, 尺骨神経麻痷の運動機能の回 復では，小指の内転可能な症例は無かった。しかし， 示指の外転，および母指内転筋の機能は，回復をみた 症例が多く, 第 3 掌側骨間筋の機能回復の不良が, 再 生軸索の伸び自体に問題をもとむべきなのか. 脱神経 筋の変性に, 主因をもとむべきものかは, 今後の検討 を要す点と考える. 神経縫合の結果の良否は, 機能 を失なった軸索を，どれだけ本来の終末蔵器と機能 的に連絡させ得たかにかかる. その為に, funicular suture の有効性が論じられておる. 分岥と吻合を くり返し Plexus を形成する Funiculus を考える と，鋭的に切断された神経を縫合する場合を除き， 数センチにわたり変性した断端の切離を行なわざるを 得ない場合では, funicular suture も限界を感じさ せられるまた，外神経鞘释合では，神経縫合部 の捻れや，ギャップがないと仮定しても 再生索軸の Misdirection が問題となる. 34 神経縫合例と 2 神経 移植例の中で， 6 神経に知覚の定位錯誤がみられた。 6 症例の知覚の回復状況は, 前述のでとく, $\mathrm{S}_{2}, \mathrm{~S}_{2}{ }^{+}$, $\mathrm{S}_{3}, \mathrm{~S}_{3}, \mathrm{~S}_{3}, \mathrm{~S}_{3}$ であった。一度成立した知覚の定位錯 哭が，再教育により改善されうるとの報告もあるが， われわれの症例では 10 年半後においても残存し続 けた. 知覚の回復と, 発汗機能との関連は, Moberg の考えがあるが, われわれの症例では, 知覚の回復状 況と発汗機能とは必ずしも平衝関係は無かった．発汗 機能を主としての知覚回復の標価法に疑問をいだかさ せられる．神経剝離術の予後は一般的には，良好であ
ったが，遅発性尺骨神経麻㾝では，症状の改善を見い 出せない症例も多く, 術前の Funicular Topography を基とした評価と，それに対する治療法の必要性を痛 感させられる.

\section{結語}

昭和 35 年より 13 年間に九大整形外科で, 治療を行 った上肢神経麻瘏 125 症例を対照に臨床的予後を検討 した.

\section{考文 献}

1）安部竜秀・他: 整形外科. 16, 762, 1965.

2) E. Moberg.: J. Bone jt. surg. 40-B. 454, 1958.

3) H. Sakellarides. : J. Bone jt. surg. 44-A. $140,1962$.

4）石川文彦・他 : 整形外科. 23，1269，1972.

5）伊藤鉄夫 - 他: 臨床整外. 1, 73, 1966.

6）伊藤鉄夫 - 他：臨床整外. 2, 51, 1967.

7) L. Onne., : Acta orthopaed. scand. suppl. $300,1962$.

8）野村 進 - 他 : 整形外科. 14, 437, 1963.

9）野村 進：整形外科. 17, 85, 1966.

10）野村 進 - 他: 整形外科. 22, 967, 1971.

11) S. Sunderland. : Brit. j. surg. 40, 580, 1953.

12）高橋正雄 - 他：臨床整外. 5, 67, 1970.

倎 問山口大学整形外科 小田 清彦 神経幹の周囲の剝離術を神経幹内の神経束の剥離術 との間に成績に差はなかったか.

\section{回答 九大整形外科 内村 正英}

Neurolysis Endneural と Extraneural に分 けて評価をしませんでしたが，教室の症例はほぼ全例 に神経鞘内に生食を注入し剥離してりく Endoneural neurolysis を行なっております.

\section{追 加 九大整形 光安 元夫}

endneural neurolysis をやるやらないという事よ り,いかに Funicular の病変を正確に術中ハアクし, 処置を加えるかが一番問題であろうと考えます. 